\title{
Apakah Theory Planned of Behaviour Dapat Mempengaruhi Perilaku Academic Fraud?
}

\author{
Sarwenda Biduri \\ Fakultas Ekonomi dan Bisnis, Universitas Muhammadiyah Sidoarjo \\ E-mail : sarwendabiduri@umsida.ac.id
}

\begin{abstract}
The purpose of this research is (1) to analyze the impact on interest behave (2) to analyze is a subjective influences interest behave (3) do control behavior perceived influences interest behave (4) is a moral obligation influences interest behavior (5) do interest behave influences behavior student academic dishonesty. This research uses the quantitative with the survey through the questionnaire and it will be distributed in stiesia, university wijaya kusuma, university trunojoyo, muhammadiyah university sidoarjo.This research using two types of variables, the independent variable and variable dependen.variabel independent is the type variables explain or affect other variables, namely kontruk attitude, subjective norm, control behavior that perceived and moral obligation.The testing of hypotheses in this research use some help software Smart PLS. The result of this research is a moral obligation significant to academic interest, control the significant to academic interest, a norm subjective do not affect significant impact on academic interest, and interest academic significant to behavior dishonesty academic.
\end{abstract}

Keywords : Academic Fraud, Theory Planned of Behaviour (TPB)

\begin{abstract}
Abstrak
Tujuan penelitian ini (1) Untuk menganalisis apakah sikap berpengaruh terhadap minat berperilaku (2) Untuk menganalisis apakah norma subyektif berpengaruh terhadap minat berperilaku (3) Apakah kontrol perilaku yang dipersepsikan berpengaruh terhadap minat berperilaku (4) Apakah kewajiban moral berpengaruh terhadap minat perilaku (5) Apakah minat berperilaku berpengaruh terhadap perilaku kecurangan akademik mahasiswa. Penelitian ini menggunakan metode kuantitatif dengan metode survey melalui kuesioner yang akan dibagikan pada STIESIA, Universitas Wijaya Kusuma, Universitas Trunojoyo, Universitas Muhammadiyah Sidoarjo. Penelitian ini menggunakan dua jenis variabel, yaitu variabel independen dan variabel dependen.Variabel independen adalah tipe variabel yang menjelaskan atau mempengaruhi variabel yang lain, yaitu kontruk sikap, norma subyektif, kontrol perilaku yang dipersepsikan dan kewajiban moral. Pengujian hipotesis dalam penelitian ini menggunakan bantuan software Smart PLS (Partial Least Square). Hasil penelitian ini adalah kewajiban moral berpengaruh signifikan terhadap minat akademik, kontrol perilaku tidak berpengaruh signifikan terhadap minat akademik, norma subjektif tidak berpengaruh signifikan terhadap minat akademik, dan minat akademik berpengaruh signifikan terhadap perilaku kecurangan akademik.
\end{abstract}

Kata Kunci : Perilaku Kecurangan, Theory Planned of Behaviour (TPB) 


\section{Pendahuluan}

Implementasi dalam kegiatan perkuliahan di Perguruan Tinggi sering dijumpai praktik-praktik menyimpang yang dilakukan mahasiswa, yang biasa disebut dengan ketidakjujuran akademik (academic dishonesty). Kecurangan akademik bisa dijelaskan sebagai sebuah tindakan kesengajaan yang dilakukan oleh pelajar, perilaku pelanggaran yang bisa saja terjadi dalam beberapa bentuk misalnya dalam hal aturan penyelesaian tugas dan ujian, dengan cara yang tidak jujur. Meskipun hal tersebut kemungkinan bisa terjadi namun di dalam perguruan tinggi, seorang mahasiswa yang memperoleh pengajaran akan menjadi calon yang profesional sesuai dengan bidang yang diambil. Menuntut sebuah perguruan tinggi agar bisa menghasilkan mahasiswa lulusan berdedikasi tinggi, bukan hanya dengan membawa bekal ilmu pengetahuan namun disertai dengan mempunyai moral dan perilaku dalam menjalankan tanggung jawabnya (Cizek dalam Riski 2009). Kecurangan dalam akademik merupakan sesuatu hal serius dalam bidang pendidikan, khususnya perkuliahan atau pendidikan tinggi (Caruana, Ramaseshan, \& Ewing, 2000; Lambert, Hogan, \& Barton, 2003; Bolin, 2004; Harding et al, 2004), bahkan dianggap sebagai masalah yang kronis (Maramark dan Maline, 1993).

Penelitian menyebutkan bahwa hampir 90\% mahasiswa melakukan cheating atau kecurangan dalam ujian mereka kerjakan (Brown dan Chang, 2005). Selanjutnya, Ameen et al., (1996) menyatakan bahwa 56\% dari mahasiswa akuntansi melakukan cheating pada saat melaksanakan ujian atau mengerjakan tugas tertulis. Dalam penelitian yang diteliti oleh Nonis dan Swift (2001) menyatakan jika pelajar yang terkait dengan perilaku kecurangan akademik disaat perkuliahan maka semakin cenderung untuk bertindak kecurangan di dunia kerja. Penelitian akuntansi yang dilakukan oleh Smith et al., (2002) mengindikasikan bahwa perilaku kecurangan yang dilakukan oleh mahasiswa mengindikasikan perilaku tidak etis saat menjadi professional. Perilaku ini akan menjadi masalah serius jika mahasiswa akuntansi yang akan menjadi professional akuntan, tidak bisa berkomitmen dalam berperilaku sesuai dengan etika yang ada di universitas (Atmeh dan Kadash, 2008). Harding et al., (2007) menggunakan model modifikasi dari Theory of Planned Behavior (TPB) yang dimiliki Beck dan Ajzen (1991) untuk memahami pengambilan keputusan etis mahasiswa teknik dan humaniora untuk terlibat perilaku kecurangan. 
Penelitian mengenai keputusan mahasiswa jurusan akuntansi yang turut berperilaku kecurangan dalam akademik menggunakan tipe model modifikasi dari TPB yang dimiliki Beck Ajzen (1991). Pengujian dengan alat modifikasi TPB pada 2 sifat ketidakjujuran akademik, yaitu kecurangan yang dilaksanakan pada saat ujian dan berbohong yang dijabarkan sebagai penggunaan alasan palsu supaya terhindar dari ujian maupun tugas yang telah diberikan. Dari penelitian tersebut memperlihatkan bahwa ada sikap, kontrol diri perilaku yang dirasakan dan kewajiban moral merupakan prediktor yang berpengaruh terhadap minat mahasiswa untuk turut serta dalam perilaku cheating dan lie, namun norma subyektif hanya berpengaruh kepada minat mahasiswa untuk berperilaku curang. TPB lebih sukses dalam memprediksi minat perilaku curang. Beck dan Ajzen (1991) mengembangkan sebuah model untuk memprediksi perilaku kecurangan akademik dari Theory of Planned Behavior. Ajzen dan Fishbein (1985) mengembangkan sebuah model yang disebut TPB yang merupakan perluasan dari Theory of Reasoned Action (TRA) milik Ajzen dan Fishbein (1975). Faktor utama dalam Theory of Planned Behavior ialah sebuah minat seseorang untuk melakukan tindakan tertentu. TPB merumuskan tiga faktor pendorong minat perilaku, yakni sikap terhadap perilaku, norma subyektif dan control perilaku yang dirasakan. Beck \& Ajzen (1991) merasa ada konstruk lain yang mempengaruhi minat berperilaku jika dikaitkan dengan perilaku kecurangan akademik.

Beck dan Ajzen (1991) menambahkan konstruk kewajiban moral sebagai salah satu faktor penentu minat berperilaku karena kewajiban moral dianggap membantu dalam memprediksi perilaku kecurangan akademik. Sehingga terbentuk sebuah model modifikasi dari Theory of Planned Behavior. Penelitian ini cenderung mengarah kepada penelitian yang diteliti oleh Beck \& Ajzen (1991) yang menggunakan model modifikasi dari Theory of Planned Behavior untuk meneliti perilaku kecurangan yang terdiri dari 4 elemen yang mempengaruhi minat berperilaku, yaitu sikap, norma subyektif, mempersepsikan sebuah kontrol perilaku, dan kewajiban dari moral. Selanjutnya kontruk minat berperilaku berpengaruh terhadap perilaku kecurangan akademik. Berdasarkan salah satu penelitian oleh Beck dan Ajzen (1991) dan Harding et al., 2007, peneliti ingin mengetahui dengan melakukan penelitian dalam sikap motivasi perilaku ketidakjujuran akademik. Penelitian ini dilakukan dengan mereplikasi model modifikasi dari Theory of Planned Behavior sedang ditingkatkan oleh Beck dan Ajzen (1991). Dari 
uraian latar belakang yang disusun diatas maka peneliti dapat membuat rumusan masalah seperti dibawah ini:

1. Perspektif sikap (attitude toward the behavior) berpengaruh terhadap minat berperilaku?

2. Perspektif norma subyektif (subjective norm) berpengaruh terhadap minat berperilaku?

3. Perspektif kontrol dari perilaku yang dipersepsikan (perceived behavioral control) berpengaruh terhadap minat berperilaku?

4. Perspektif kewajiban moral (moral obligation) berpengaruh terhadap minat berperilaku?

5. Perspektif minat berperilaku (intention) berpengaruh terhadap perilaku kecurangan akademik mahasiswa?

Untuk tujuan dalam penelitian kali ini ialah untuk menganalisis apakah sikap berpengaruh terhadap minat berperilaku, untuk menganalisis apakah norma subyektif berpengaruh terhadap minat berperilaku untuk mengetahui apakah kontrol perilaku yang dipersepsikan berpengaruh terhadap minat berperilaku, untuk mengetahui apakah kewajiban moral berpengaruh terhadap minat perilaku dan untuk mengetahui apakah minat berperilaku berpengaruh terhadap perilaku kecurangan akademik mahasiswa.

\section{Metode}

Penelitian saat ini menggunakan pendekatan kuantitaif karena berfokus pada teori-teori lewat pengukuran variabel penelitian menggunakan nominal dan melaksanakan analisis data dengan prosedur statistik. Penelitian saat ini menggunakan pendekatan kuantitaif dengan menggunakan metode survey, dimana metode ini adalah metode yang memberi pertanyaan terstruktur kepada sampel dari populasi \& dirancang untuk memperoleh informasi dari respondens.

Populasi yang ditetapkan mahasiswa jurusan S1 akuntansi di empat Perguruan Tinggi yang ada di Jawa Timur, yaitu Sekolah Tinggi Ilmu Ekonomi Indonesia (STIESIA) Surabaya, Universitas Wijaya Kusuma Surabaya, Universitas Trunojoyo Madura, dan Universitas Muhammadiyah Sidoarjo. Pemilihan sampel pada peneitian ini menggunakan metode pemilihan secara acak (random sampling). 
Dalam penelitian kali ini peneliti menggunakan variabel Sikap, Norma Subyektif, Kontrol Perilaku Yang Dipersepsikan, Kewajiban Moral sebagai variabel bebas (independen) dan Minat, Perilaku Kecurangan Akademik sebagai variabel terikat (dependen). Dalam penelitian ini peneliti menggunakan data kuantitatif.

Penelitian saat ini menggunakan 2 jenis variabel, yaitu variable independen \& variable dependen. Variabel independen adalah tipe variabel yang menjelaskan atau mempengaruhi variabel yang lain, yaitu kontruk sikap, norma subyektif, kontrol perilaku yang dipersepsikan dan kewajiban moral. Variabel dependen adalah tipe variabel yang dijelaskan atau dipengaruhi oleh variabel independen, yaitu konstruk minat dan perilaku kecurangan akademik. Konstruk pertama yaitu sikap (X1). Sikap terhadap perilaku dijelaskan sebagai perasaan mendukung / memihak (favorableness) atau perasaan tidak mendukung ataupun tidak memihak (unfavorableness) terhadap suatu objek yang akan disikapi (Beck danAjzen, 1991). Indikator konstruk sikap diukur dengan menggunakan tujuh item pertanyaan berdasarkan konsep Stone et al., (2010).

Konstruk kedua adalah norma subyektif (X2). Norma subjektif(subjective norm) dijelaskan sebagai pengaruh dari orang -orang disekitar yang direferensikan (Ajzen, 1991). Indikator konstruk norma subyektif diadaptasi dari konsep penelitian yang dilakukan oleh Harding et al.,(2007). Konstruk ketiga adalah kontrol perilaku yang dipersepsikan (X3). Ajzen (2002) mendefinisikan kontrol perilaku dianggap sebagai cara termudah yang dirasakan dari manfaat melakukan perilaku berdasarkan pengalaman masalalu \& hambatan yang di antisipasi. Indikator konstruk kontrol perilaku yang dipersepsikan diukur dengan empat item pertanyaan yang diadopsi dari konsep Stone et al., (2010). Konstruk keempat adalah kewajiban moral (X4).

Software Smart PLS (Partial Least Square) digunakan dalam penelitian ini sebagai pengujian hipotesis. Partial Least Square merupakan teknik statistik multivariat yang menerapkan perbandingan antara variable dependen berganda \& variable independen berganda (Jogiyanto dan Abdillah,2009). Terdapat 2 evaluasi yang dipergunakan dalam penelitian saat ini, yaitu evaluasi outer model yang terdiri dari uji validitas variable (validitas konvergen \& validitas diskriminan), uji reliabilitas dengan menggunakan 2 metode yaitu cronbach's alpha \& composite reliability. Selanjutnya evaluasi inner model yang menggunakan R2 \& menggunakan nilai koefisien path atau $t$-values tiap path untuk uji signifikannsi antar variabel dalam model struktural. 


\section{Hasil dan Pembahasan}

Hasil pengujian analisis pada penelitian ini dapat dijelaskan melalui hasil Goodness Of Fit Model, Pengujian Hipotesis, dan Konversi Diagram Jalur Kedalam Model Struktural yang dirincikan sebagai berikut:

1. Reliabelity Konstruk

a. Composite Reliabelty, Crombach Alpha dan Average Variance Extracted (AVE)

Kriteria reliabilitas dilihat dari nilai composite reliabilitas suatu konstruk, Crombach Alpha \& nilai Average Variance Extracted (AVE) dari tiap-tiap konstruk. Konstruk dikatakan memiliki reliabilitas yangg tinggi jika nilainya 0,70, Crombach Alpha diatas 0.60 dan AVE berada diatas 0,50. Pada tabel 1 akan disajikan nilai Composite Reliability, Crombach Alpha dan AVE untuk seluruh variable.

Tabel 1

Composite Reliability, Crombach Alpha dan AVE

\begin{tabular}{|c|c|c|c|}
\hline & $\begin{array}{l}\text { Cronbach's } \\
\text { Alpha }\end{array}$ & $\begin{array}{l}\text { Composite } \\
\text { Relishility }\end{array}$ & $\begin{array}{l}\text { Average } \\
\text { Variance } \\
\text { Fxtracted } \\
\text { (AVF) }\end{array}$ \\
\hline Kcwajihan Mors1 & 0676 & 0.816 & ก 601 \\
\hline Kontrol Perilalou & 0.77 & 0.866 & 0.685 \\
\hline Minas. & 1 & 1 & 1 \\
\hline Norma Subicktif & 0674 & 0817 & 0599 \\
\hline Tcrilskukctidakjujuman & 1 & 1 & 1 \\
\hline Sikap & 0.818 & 0.087 & 0.511 \\
\hline
\end{tabular}

Sumber: Olah Data SmartPLS 3.0

Berdasarkan hasi pengujian reliabelitas Composite Reliability, Crombach Alpha dan AVE pada table 1 diatas dapat dijelaskan sebagai berikut:

a. Nilai composite reliability dari keempat variabel memiliki nilai lebih besar dari 0.70 dengan demikian composite reliability keempat variabel dinyatakan reliable

b. Nilai Crombach Alpha dari keempat variabel memiliki nilai lebih besar dari 0.60 dengan demikian Crombach Alpha keempat variabel dinilai reliable.

c. Nilai AVE dari keempat variabel memiliki nilai > dari 0.50 dengan demikian AVE keempat variabel dinilai reliable 


\section{Outer Loading}

Pengujian validitas konstruk pada model reflektif ditunjukkan dengan nilai signifikan pada Outer Loading sebagai berikut

Tabel 2

Outer Loading

\begin{tabular}{|c|c|c|c|c|}
\hline & \begin{tabular}{|l} 
Or.ginal \\
Surrole \\
(0)
\end{tabular} & \begin{tabular}{|l} 
jar.qke \\
$M=: n$ \\
$M a$
\end{tabular} & $\begin{array}{l}\text { Standart } \\
\text { Devintar } \\
\text { (STDFV) }\end{array}$ & $\begin{array}{l}\text { TStatiess } \\
\text { (astDEV0 }\end{array}$ \\
\hline 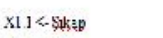 & $(2.6)$ & $0.4: 1$ & 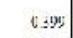 & $\left.4 . A_{2}\right)$ \\
\hline $\mathrm{X} 12<\mathrm{S} \mathrm{S} ; \mathrm{R}$ & C.372 & 0.105 & C.335 & 3.112 \\
\hline 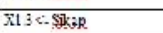 & 6800 & 0.336 & $C A: 8$ & 4.456 \\
\hline 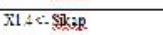 & C379 & 0.408 & $c 3: 6$ & 3.199 \\
\hline 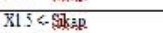 & 0.47 & 0.403 & $c 448$ & 2006 \\
\hline $\mathrm{Xl} 5<$ salkap & $0 .(9)$ & 0.393 & 0.43 & 2.56 \\
\hline $\mathrm{Xl}$ \% & 0.46 & 0.381 & $0 \div: 8$ & 2.043 \\
\hline $\mathrm{x} 2 \mathrm{1}<$. Norma Striekttf & 0.501 & 0.662 & 0.167 & 4.19. \\
\hline 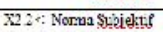 & C.778 & 0.759 & 0.123 & 6.303 \\
\hline 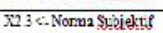 & $\cos 38$ & $0.8: 5$ & C.097 & 9.617 \\
\hline 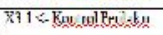 & C.351 & 9864 & $\overline{D O S}$ & 974 \\
\hline 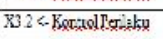 & 0.766 & 0.74 & $0.1: 4$ & 6.725 \\
\hline 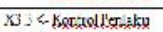 & l. .532 & $0.8: 5$ & $0.1: 3$ & $? 3,3$ \\
\hline 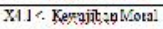 & 0.816 & 0.813 & 0.04 & $2 . .197$ \\
\hline 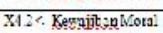 & C.811 & 0.836 & $\operatorname{coss}$ & 2.732 \\
\hline 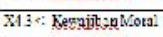 & c.5:5 & $0.6: 1$ & 0.1 & $6.15:$ \\
\hline Pl< liva & $T$ & $T$ & ? & \\
\hline 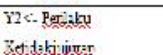 & 1 & 1 & c. & \\
\hline
\end{tabular}

Sumber: Olah Data Smart PLS 3.0

Berdasarkan hasil Outer Loading yang dihasilkan dapat diketahui bahwa semu indicator masing-masing dimensi sikap, norma subjektif, control perilaku, kewajiban moral, minat dan perilaku kecurangan akademik memiliki Outer Loading lebih besar dari 0.30 dengan demikian indikator tersebut dinyatakan valid sebagai penguku variabel laten.

3. Rancangan Model Struktural

Rancangan Model Struktural (Inner Model) dalam penelitian ini dapat ditunjukkan pada gambar 2 dibawah ini: 
Gambar 2

Model Struktural (Inner Model)

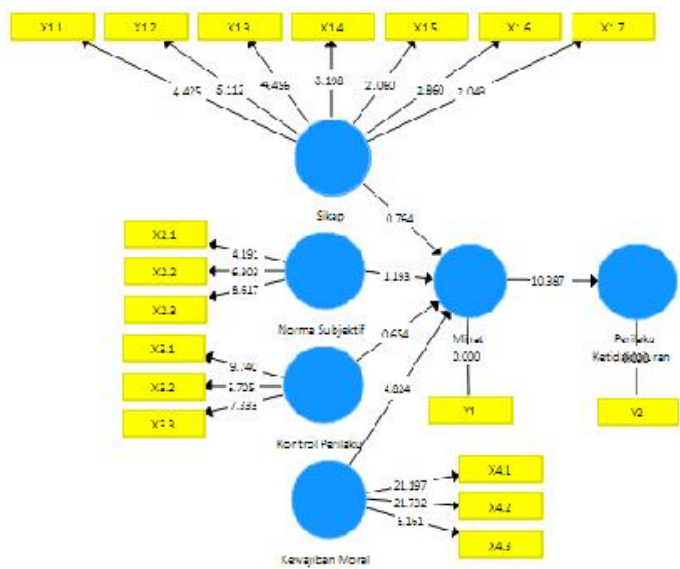

Sumber: Olah Data Smart PLS 3.0

4. Goodness Of Fit Model

Dalam menilai model dengan PLS dimulai dengan melihat $R$-square untuk setiap variabel laten dependen. Tabel 3 merupakan khasil estimasi $R$-square dengan menggunakann Smart PLS yang ditunjukkan sebagi berikut:

Tabel 3

R-square

\begin{tabular}{|l|l|}
\hline & R-square \\
\hline Minat & 0.187 \\
\hline Perilaku & 0.416 \\
Ketidakiujuran & \\
Akademik & \\
\hline
\end{tabular}

Sumber: Olah Data Smart PLS 3.0

$R^{2}=1-\sqrt{1-R^{2} e 1} * \sqrt{1-R^{2} e 1}$

$R^{2}=1-\sqrt{1-0.187} * \sqrt{1-0.416}$

$R^{2}=1-\sqrt{0.813} * \sqrt{0.584}$

$R^{2}=1-\sqrt{0.474792}$

$R^{2}=0.311$ 
Berdasarkan hasil pengujian $R$-square pada table 3 diatas dapat dijelaskan sebagai berikut:

a. Nilai $\mathrm{R}^{2}$ pada variabel Minat sebesar 0.187, hal ini dapat diartikan bahwa kontribusi variabel Sikap, Norma Subjektif, Kontrol Perilaku dan Kewajiban Moral Terhadap variabel Minat sebesar 0.187 atau 18.7\%. sedangkan sisanya 100\% $18.7 \%=81.3 \%$ merupakan kontribusi dari variabel lain.

b. Nilai $\mathrm{R}^{2}$ pada variabel Perilaku Kecurangan Akademik sebesar 0.416, hal ini dapat diartikan bahwa Minat Terhadap variabel Perilaku Ketidakjujuran Akademik sebesar 0.416 atau $41.6 \%$. sedangkan sisanya $100 \%-41.6 \%=58.4 \%$ merupakan kontribusi dari variabel lain.

c. Nilai $\mathrm{R}^{2}$ sebesar 0.311 hal ini dapat dijelaskan bahwa kontribusi model parth yang terdiri dari variabel Sikap, Norma Subjektif, Kontrol Perilaku, Kewajiban Moral dan Minat Terhadap variabel Perilaku Ketidakjujuran Akademik sebesar 0.311 atau $31.1 \%$. sedangkan sisanya $100 \%-31.1 \%=68.9 \%$ merupakan kontribusi variabel lain yang tidak dibahas.

5. Pengujian Hipotesis

Hasil pengujian hipotesis menunjukkan bahwa nilai signifikansi parameter yang diestimasi memberikan informassi yang amat sangat berguna sesuai hubungan antara variabel-variable penelitian. Dasar yang digunakan dalam menguji hipotesis yaitu nilai yang terdapat pada output result for inner weight. Tabel 5.2 menghasilkan output estimasi untuk pengujian model structural.

Tabel 4

Result For Inner Weight

\begin{tabular}{|c|c|c|c|c|c|}
\hline & $\begin{array}{l}\text { Originel } \\
\text { Ssmple } \\
\text { (O) }\end{array}$ & \begin{tabular}{|l|} 
Sample \\
Mcan \\
(MD
\end{tabular} & $\begin{array}{l}\text { Standixr } \\
\text { Deviation } \\
\text { (STDEV) }\end{array}$ & $\begin{array}{l}\text { I Stahtetice } \\
\text { O/STLEV D }\end{array}$ & PVidues \\
\hline $\begin{array}{l}\text { Bexaitben } \\
\text { Moral - } \\
\text { Mngat }\end{array}$ & 0.104 & 0.146 & 0.034 & 1.821 & 0.050 \\
\hline $\begin{array}{l}\text { Kunltul } \\
\text { Rertaku }= \\
\text { Mingt }\end{array}$ & -0.049 & -0.043 & 0.075 & 0.654 & 0.513 \\
\hline $\begin{array}{l}\text { Minat - }> \\
\text { Ferilaku } \\
\text { Keridakjivitan }\end{array}$ & $064 i$ & $0 \times 43$ & $005 \%$. & 10337 & 0000 \\
\hline $\begin{array}{l}\text { Norma } \\
\text { Sybieltif }> \\
\text { Ningt }\end{array}$ & 0.091 & 0.132 & 0.076 & 1.123 & 0.233 \\
\hline $\begin{array}{l}\text { Silkap - } \\
\text { Nipat }\end{array}$ & -0.151 & -0.098 & 0.197 & 0.754 & 0.445 \\
\hline
\end{tabular}

Sumber: Olah Data Smart PLS 3.0 
Berdasarkan hasi pengujian Result For Inner Weight pada table 4 diatas dapat dijelaskan sebagai berikut:

a. Hasil estimasi hubungan variabel kewajiban terhadap minat menunjukkan nilai koefisien jalur sebesar 0,404 dengan nilai t sebesar 4.824 . Nilai tersebut $>$ dari $\mathrm{t}$ tabel $(1,960)$. Hasil tersebut menerangkan bahwa kewajiban moral berpengaruh signifikan terhadap minat akademik dimana kewajiban moral untuk menolak adanya kecurangan akademik masih mulai terlaksana dan ditanamkan perasaan untuk tidak melakukkan kecurangan akademik.

b. Hasil estimasi hubungan variabel kontrol perilaku terhadap minat menunjukkan nilai koefisien jalur sebesar -0,049 dengan nilai t sebesar 0.654 . Nilai tersebut lebih kecil dari t tabel $(1,960)$. Hasil ini berarti bahwa kontrol perilaku tidak berpengaruh signifikan terhadap minat akademik dimana kontrol perilaku yang dilakukkan oleh mahasiwa dan mahasiswi belum dilakukkan sehingga kecurangan akademik semakin muncul.

c. Hasil estimasi hubungan variabel norma subjektif terhadap minat menunjukkan nilai koefisien jalur sebesar 0,091 dengan nilai t sebesar 1.193. Nilai tersebut lebih kecil dari t table $(1,960)$. Hasil ini berarti bahwa norma subjektif tidak berpengaruh signifikan terhadap minat akademik dimana norma subjektif untuk mengetahui kaidah-kaidah dari orang lain yang dianggap penting masih belum terlaksana dengan baik sehingga mahasiwa dan mahasiswi masih melakukkan tidakan kecurangan akademik.

d. Hasil estimasi hubungan variabel sikap terhadap minat menunjukkan nilai koefisien jalur sebesar -0.151 dengan nilai $t$ sebesar 0.764 . Nilai tersebut lebih kecil dari $t$ tabel (1,960). Hasil tersebut berarti bahwa sikap tidak berpengaruh signifikan terhadap minat akademik dimana sikap atau perilaku yang ditunjukkan oleh mahasiswa dan mahasiwi masih terbilang kurang memiliki keyakinan terhadap tindakan kecurangan akademik dan masih banyak yang menghiraukan konsekuensi yang telah di tentukan

e. Hasil estimasi hubungan variabel minat terhadap perilaku ketidakjujuran akademik menunjukkan nilai koefisien jalur sebesar 0,645 dengan nilai sebesar 10.387. Nilai tersebut $>$ dari $\mathrm{t}$ tabel $(1,960)$. Hasil ini berarti bahwa minat berpengaruh signifikan terhadap perilaku kecurangan akademik dimana minat 
untuk tidak melukkan perilaku kecurangan akademik sangat penting karena ladasan utama adalah minat mahasiwa atau mahasiswi untuk merubah sikap, norma subjektif, kontrol perilaku \& kewajiban moral dapat agar perilaku kecurangan akademik tidak terlaksana tetapi secara nyata perilaku ketidakjujuran akademik masih dilakukkan oleh mahasiwa atau mahasiswi.

\section{Konversi Diagram Jalur Kedalm Model Struktural}

Konversi diagram jalur kedalam model structural digunakan untuk mengetahui bagaimana pengaruh antara variabel eksogen dan endogen yang deskripsikan pada efek model, yakni efek langsung dan tidak langsung yang ditunjukkan pada table 5.3 dibawah ini:

Tabel 5

Konversi Diagram Jalur

\begin{tabular}{|l|r|r|r|}
\hline & Direct & Indirect & Total \\
\hline $\begin{array}{l}\text { Kewajiban } \\
\text { Moral -> } \\
\text { Minat }\end{array}$ & & & \\
\hline $\begin{array}{l}\text { Kontrol } \\
\text { Perilaku }>> \\
\text { Minat }\end{array}$ & 0.404 & - & 0.404 \\
\hline $\begin{array}{l}\text { Minat - } \\
\text { Perilaku } \\
\text { Ketidakiujuran }\end{array}$ & 0.645 & - & 0.645 \\
\hline $\begin{array}{l}\text { Norma } \\
\text { Subjektif -> } \\
\text { Minat }\end{array}$ & 0.049 & - & 0.049 \\
\hline $\begin{array}{l}\text { Sikap - } \\
\text { Minat }\end{array}$ & 0.091 & - & 0.091 \\
\hline
\end{tabular}

Sumber: Olah Data Smart PLS 3.0

Berdarkan hasil konversi diagram jalur pada table 5 diatas dapat dijelaskan sebagai berikut:

a. Koefisien direct effect kewajiban moral terhadap minat sebesar 0.404 menunjukkan kewajiban moral berpengaruh positif signifikan terhadap minat dimana meningkatnya kewajiban moral akan menaikkan minat untuk tidak melakukkan kecurangan akademik. 
b. Koefisien direct effect kontrol perilaku terhadap minat sebesar -0.049 menunjukkan kontrol perilaku berpengaruh negative tidak signifikan terhadap minat dimana meningkatnya kontrol akan menurunkan minat sehingga berdampak akan semakin melakukkan tindakan kecurangan akademik.

c. Koefisien direct effect norma subjektif terhadap minat sebesar 0.091 menunjukkan norma subjektif berpengaruh positif tidak signifikan terhadap minat dimana meningkatnya norma subjektif akan menurunkan minat sehingga berdampak akan semakin melakukkan tindakan kecurangan akademik.

d. Koefisien direct effect sikap terhadap minat sebesar -0.151 menunjukkan sikap berpengaruh negatif tidak signifikan terhadap minat dimana meningkatnya sikap akan menurunkan minat sehingga berdampak akan semakin melakukkan tindakan kecurangan akademik.

e. Koefisien direct effect minat terhadap perilaku kecurangan akademik sebesar 0.645 menunjukkan minat berpengaruh positif signifikan terhadap perilaku kecurangan akademik dimana meningkatnya kewajiban moral akan menaikkan minat untuk tidak melakukkan kecurangan akademik.

\section{Kesimpulan}

Berdasarkan hasil analisis dan pembahasan diatas dapat disimpulkan bahwa variabel kewajiban moral berpengaruh signifikan terhadap minat akademik, variabel kontrol perilaku tidak berpengaruh signifikan terhadapp miinat akademik, variabel norma subjektif tidak berpengaruh signifikan terhadap minat akademik, variabel sikap tidak berpengaruh signifikan terhadap minat akademik, variabel minat berpengaruh signifikan terhadap perilaku kecurangan akademik.

Pada penelitian ini tentunya terdapat keterbatasan penelitian, dalam penelitian ini, variabel yang digunakan hanya tebatas pada variabel yang biasa terdapat pada Theory Planned Of Behaviour saja, karena tidak menutup kemungkinan terdapat variabel lain diluar variabel-variabel tersebut. 


\section{Daftar Pustaka}

Achmat, Zakarija. 2010. "Theory of Planned Behavior, Masihkah Relevan?" http://zakarija.staff.umm.ac.id/download-as-pdf/umm_blog_article_112. pdf, diakses 14 November 2014.

Ajzen, I. 2012. The theory of planned behavior.In P. A. M. Lange, A. W.

Ajzen, I., \& Sheikh, S. 2013. Action versus inaction: Anticipated affect in the theory of planned behavior. Journal of Applied Social Psychology, 43(1), 155-162.doi: 10.1111/j.1559-1816.2012.00989.x

Alleyne, P and K. Phillips. 2011. Exploring Academic Dishonesty Among University Students in Barbados: An Estension to the Theory of Planned Behavior. J.Acad Ethics (9), 323-338. Springers Science, Business Media B.V 2011.

Anitsal, I., Anitsal, M. M., \& R. Elmore. 2009. Academic Dishonesty and Intention to Cheat: A Model on Active Versus Passive Academic Dishonesty asPerceived by Business Students. Academy of Educational LeadershipJournal, Volume 13 (2).

Anderman E. M. Dan Murdock T. B. 2007. Psychology of Academic Cheating. London : Academis Press, Inc.

Atmeh, $\mathrm{M}$ and $\mathrm{H}$. Al-Khadash. 2008. Factors Affecting Cheating Behavior among Accounting Students (Using the Theory of Planned Behavior).Journal ofAccounting - Business \& Management 15, 109-125.

Beck, L., \&Ajzen, I. 1991.Predicting dishonest actions using the theory of planned behavior. Journal of Research in Personality, 25, 285-301.

Caruana, Albert., B. Ramaseshan., Michael T. Ewing. 2000. The effect of anomie on academic dishonesty among university students. The International Journal ofEducational Management 14/1. 23-30.

Davis, S. F. Drinan, P. F. Gallany, T. B. 2009. Cheating in School : What We Know and What We Can Do. Chicester : Wiley Blackwell.

Eastman, J.K., R. Iyer\& T. H Reisenwitzs. 2008. The Impact Of Unethical Reasoning On Different Types Of Academic Dishonesty: An ExploratoryStudy. Journal of College Teaching \& Learning. Volume 5, number 12.

Indriantoro, Nur dan Bambang Supomo. 2011, "MetodologiPenelitian Bisnis Untuk Akuntansi Dan Manajemen",Edisi Pertama. BPFE,Yogyakarta.

Istijanto. 2008. Riset Sumber Daya Manusia. Edisi ketiga. Jakarta : PT. Gramedia Pustaka.

Jogiyanto, H. M dan W. Abdillah. 2009. Konsep dan Aplikasi PLS (Partial Least Square) untuk Penelitian Empiris. Yogyakarta: BPFE UGM.

Kuncoro, Mudrajad. 2011. Metode Kuantitatif: Teori dan Aplikasi untuk Bisnis dan Ekonomi. Yogyakarta:UPP STIM YKPN.

Lambert, Eric G., Nancy L. Hogan., Shannon M. Barton. 2003. Collegiate Academic Dishonesty Revisited:What Have They Done, How Often Have They Done It, Who Does It, And Why Did They Do It?. Electronic Journal of Sociology.Produced by CAAP.

McCabe, D. L. (2010). Poor Work Ethics Risk Future of U.S Business, Education and Ultimately Freedom. Rutgers Business School Newark and New Brunswick. Diunduh pada 29 Oktober 2013 pukul 16.33 WIB dari sumber: www.business.rutgers.edu/tags/332/page $=1$. 
Maramark, Sheilah \& Maline, Mindi Barth. 1993. Academic Dishonesty Among College Students.Issues in Education. Office of Educational Research and Improvement (ED). Washington, DC. Office of Research.

Rangkuti, A. A. 2011. Academic cheating behaviour of accounting students: A case study in Jakarta State University. In Educational integrity: Culture and Values. Proceedings 5th Asia Pacific Conference on Educational Integrity.The University of Western Australia, 26-28 September. 105109)http://www.apcei.catl.uwa.edu.au/procs/rangkuti.pdf

Rahman, Anindya Dianita. 2012. Pengaruh Sikap, Norma Subyektif, dan Kendali Keperilakuan pada Niat Perilaku Siswa-Siswi SMAN 7 Malang dalam Memilih Jurusan Akuntansi Sebagai Jurusan Perkuliahan. Skripsi. Malang: Fakultas Ekonomi dan Bisnis Universitas Brawijaya.

Samani, M., \& Hariyanto. 2012.Konsep dan Model Pendidikan Karakter. Bandung: Remaja Rosdakarya.

Singarimbun, Masri, dan Sofian Effendi, Metode Penelitian Survei, Pustaka LP3ES Indonesia, Jakarta, 2013.

Smith et al. 2002.A Structural Modeling Investigation of The Influnce of Demographic and Attidinal Factors and in-class Deterrens of CheatingBehavior among Accounting Students. Journal of Accounting Education, 20,45-65.

Sugiyono. 2012. Metode Penelitian Kuantitatif, Kualitatif, dan $R$ \& D. Penerbit: Alfabeta, Bandung. 